\title{
ГСом \\ Structure and development of science communication research: co-citation analysis of a developing field
}

\section{Adrian Rauchfleisch and Mike S. Schäfer}

Abstract

Keywords

DOI
Since the early 1990s, there has been a considerable increase in the number of scientific studies on science communication, and this increase has been accompanied by a diversification of the research field. This study focuses on one aspect of this development: it analyses how citation network structures within the field have developed over time, and whether science communication research shows signs of becoming a research field or a discipline in its own right. Employing a co-citation analysis of scholarly publications published between 1996 and 2015, it assesses to what extent a coherent communication network exists within science communication research. The results show a field with a diverse internal structure and clear internal changes over time which suggest an increasing emancipation of the field.

Scholarly communication; Science communication: theory and models

https://doi.org/10.22323/2.17030207

Along with the rising importance of science communication itself, the scientific community has started to analyze the characteristics, antecedents and effects of science communication. Research interest emerged in the 1990s from disciplinary fields like sociology [e.g. Bucchi, 1998; Peters, 1994; Weingart, 1998], media and communication science [e.g. Dunwoody, 1980; Goodell, 1977; Ruhrmann, 1992], or political science [e.g. Miller, 1991; Miller, 1998], as well as from interdisciplinary fields like the "science and technology studies" [e.g. Callon, 1995; Lewenstein, 1995], among others. Since then, there has been a considerable increase in the number of scientific studies on science communication [Guenther and Joubert, 2017; Schäfer, 2012]. In addition, and even though most authors of scientific publications in the field are still based in the U.S. [Guenther and Joubert, 2017, 10f], the objects of analysis have become more diverse, moving away from a strong early focus on the Anglophone world and on national, quality print media; and research designs and methods have diversified as well [Schäfer, 2011; Schäfer and Schlichting, 2014].

Along with this quantitative growth and diversification, a stronger institutionalization of the field and an increasing emancipation from mother disciplines and neighboring fields have been diagnosed by some scholars [for a differing position see Trench and Bucchi, 2010]. They have argued that research on 
science communication has become "an independent academic field, different from both science and technology studies and communication and media theory" [Gascoigne et al., 2010, p. 1; cf. Bauer, 2009; Delfanti, 2008]. It has even been cautiously debated in JCOM - Journal of Science Communication whether the field "has achieved the status of a discipline" [Gascoigne et al., 2010, p. 5].

This study focuses on one aspect of this development: it analyses how citation network structures within the research field have developed over time. Employing a co-citation analysis of scholarly publications, it assesses to what extent a coherent "communication network" [Gascoigne et al., 2010, p. 4] exists within the field, or to what extent different networks continue to co-exist. In doing so, it analyzes a) how homogenous the field is, i.e. if and how many subcommunities with their own citation structures can be found, b) how they have developed over time and c) how strong the linkages between those subcommunities are. Answering these questions allows us to assess if science communication research has indeed become institutionalized, at least with regards to the formal communication of scholars in this field, and if so, when and how it has differentiated itself from other fields or disciplines.

\section{Conceptual framework: communicative networks as core characteristics of research fields}

"Discipline" and "research field" are commonly-used terms in the history and philosophy of science. Nonetheless, it is difficult to define these concepts precisely, as "[ $t$ ]here is considerable ambiguity in the concept" [Sugimoto and Weingart, 2015, p. 775]. Understandings of disciplines, for example, have been developed in different ways, based on different criteria, and have, consequently, come to different descriptions [for an overview see Sugimoto and Weingart, 2015, pp. 778ff.]. Some are based on theoretically developed, deductive conceptualizations which organize disciplines according to their "cognitive coherence" [Bulick, 1982, p. 12], to the existence of a social community of scholars [e.g. Lattuca, 2002], the existence of a specific language [e.g. Krishnan, 2009] or communicative network [Sugimoto and Weingart, 2015]. Other understandings are based on disciplinary narratives emphasizing founding figures or influential publications, crucial conferences or pressing social needs that led to the establishing of certain disciplines [Sugimoto and Weingart, 2015]. In addition, there are - partly idiosyncratic - conceptualizations of disciplines that have been developed, implicitly or explicitly, around certain measurements, i.e. around publication- or author-based metrics or around certain languages, topics or ideas which are used to distinguish disciplines [Sugimoto and Weingart, 2015].

As a result, diverse understandings of disciplinarity exist, which poses a difficulty for an empirical study. This difficulty can be remedied, however, with two conceptual specifications: firstly, scholars like Good [2000] argue that "disciplinarity is not a yes or no proposition" (p. 260), and that disciplines have to be understood as "ever-changing frameworks within which scientific activity is organized" [Good, 2000, p. 260]. Therefore, the boundaries between a research field and a discipline are fluid, and come down to the degree to which definitorial core characteristics of disciplines are fulfilled.

Secondly, scholars have acknowledged that the number of such core characteristics, which are repeatedly described in scholarly literature, is limited. "[T] here are a few common axes upon which conceptualizations, disciplinary narratives, and 
measurements revolve" [Sugimoto and Weingart, 2015, p. 775]. Three such 'axes' seem to be most common in the respective literature [see Gascoigne et al., 2010; Schützenmeister, 2008]: firstly, research fields and disciplines are distinguished along institutional characteristics, i.e. according to whether they have their own conferences, professional associations, outlets for publication etc. Secondly, they are delineated along epistemic characteristics, i.e. according to whether they have a common object, epistemic history and joint modes of scholarly inquiry. Thirdly, research fields and disciplines are often distinguished based on social and communicative characteristics.

The first two of these axes have been repeatedly described with regards to research on science communication. In the case of its institutional characteristics, scholars have portrayed it as an increasingly institutionalized research field, relying on a broad range of indicators. Firstly, they have pointed towards established professional associations and their conferences. They emphasize the international Public Communication of Science and Technology (PCST) Network, for example, which was founded in the 1980s, "and held its first international conference in 1989. Since then it has held 16 formal international conferences and one symposium in cities from Madrid and Montreal to Cape Town and Seoul. Recent conferences attracted 500-700 registrants from 50 different countries" [Gascoigne et al., 2010, p. 2]. They also emphasized other associations and meetings, like the "American Association for the Advancement of Science (AAAS) [which] has a strong tradition of science communication", the Association of British Science Writers, or the European Science Events Association with "89 member organisations from 34 countries" [Gascoigne et al., 2010, p. 2]. Secondly, they have pointed towards the journals which have become established in the field, such as "Public Understanding of Science", "Science Communication" or "JCOM - Journal of Science Communication" [e.g. Gascoigne et al., 2010, p. 3], and the various introductory and handbooks which have been published [e.g. Bauer and Bucchi, 2007; Fähnrich et al., 2018; Bucchi and Trench, 2014; Bonfadelli et al., 2018; Fischhoff and Scheufele, 2013; Gregory and Miller, 1998; Hall Jamieson, Kahan and Scheufele, 2017; Nisbet et al., 2017]. In addition, in many countries, assessments of adult scientific literacy have been established which regularly evaluate science knowledge, comprehension and attitudes [cf. Bauer, 2009]. Thirdly, they have described how science communication has been established in higher education, e.g. in chairs at universities in different countries, in "formal training at college and university levels [which] began to take shape from 1980", with the U.S. Directory of Science Communication Courses and Programs listing " 51 courses and programs at 44 separate universities" or the The European Guide to Science Journalism including courses in 27 countries, and many more courses being "offered throughout the world" [Gascoigne et al., 2010, p. 3]. Overall, with regards to institutional characteristics, a number of scholarly observations show a rather clear trend towards an established, autonomous field devoted to science communication research.

Regarding epistemic characteristics, scholars have described the emergence and development of core concepts, and of related measurements as a central characteristic of research fields and disciplines. Even though the field is interdisciplinary in its origin and in its approach to many of its questions, it has been argued that it has developed a portfolio of specific concepts and measurements [Gascoigne et al., 2010]. Concepts and models specific to the field have been developed, like the early "public understanding of science" approach or 
"deficit model" [e.g. Bauer, 2009], ${ }^{1}$ or the "public engagement with science and technology" approach [e.g. Bucchi, 2008; Schäfer, 2009]. In addition [and even though some of the older concepts are difficult to get rid of in public debate, see the current issue of PUS on "deficit model" Bauer, 2016], an elaboration of these concepts is visible over time - with the field, e.g., moving from "public understanding of science" and "deficit model" approaches to more elaborate "Science in Society" approaches like "public engagement with science and technology" which take the two-way, dialogical nature of communication and an active audience into account [e.g. Bauer, Allum and Miller, 2007; Gregory and Miller, 1998; Schäfer, 2009], or with the field elaborating on earlier approaches of "scientific literacy" [Miller, 1983] in terms of dimensionality [e.g. Miller, 1998], measurement [e.g. Pardo and Calvo, 2002] and concept [Kahan, 2016]. The available publications show that, while models and concepts have been (and still are often) imported into the field, they have been adapted. Nowadays, a number of approaches, theories and models exist which are specific to science communication research.

In contrast to the institutional and epistemic characteristics of science communication research, their communicative networks have not yet been sufficiently scrutinized. While "[c]ommunication is recognized as a crucial component of disciplinarity, thus reinforcing the use of formal scholarly communication in measurements of disciplinarity" [Sugimoto and Weingart, 2015, p. 787], the analysis of science communication research exhibits considerable shortcomings in this respect. Analyses of communication in this field have either focused on the extent of institutionalized communication on conferences as measured in participants or presentations [e.g. Gascoigne et al., 2010], or they have analyzed scholarly publications without looking for network structures [e.g. Guenther and Joubert, 2017; Gurabardhi, Gutteling and Kuttschreuter, 2004; Schäfer, 2012]. These analyses have shown, for example, that the number of publications has increased [Schäfer, 2012], with a "steady stream of books on science communication reach[ing] the market every year", the field having a "strong record of articles", and the respective conferences having hundreds of papers and participants [Gascoigne et al., 2010, p. 3]. Scholars have not gone beyond literature reviews which, however, rarely focus on the communicative networks existing in the field [e.g. Gregory and Miller, 1998; Bucchi and Trench, 2014], even though written scholarly communication offers a way to do so, and even though a history of bibliometric analysis exists which provides tools to analyze these networks [for an overview see Diodato and Gellatly, 2013].

Objectives of the study
To address this gap in scholarship, we provide a bibliometric analysis of publications from studies of science communication. Using co-citation analysis, we assess the communicative networks within the field as one of the crucial facets of the development of research fields. This approach helps us to identify specific subgroups in the field. A co-citation analysis counts how often two "items of earlier literature are cited together by the later literature" [Small, 1973, p. 265]. Of course, this purely quantitative criterion is only one possible approach to measure "disciplinarity" and there are other, more qualitative criteria that Sugimoto and

\footnotetext{
${ }^{1}$ Those concepts partly also rested on conceptual foundations taken from other fields. The deficit model, for example, shows parallels to Freire's "banking" model in educational science [Freire, 1985].
} 
Weingart [2015] propose. Still, "co-citation analysis is useful for rendering the inertia of fields" [White and McCain, 1998, p. 342].

This general aim translates into three research objectives: firstly, we will analyze which co-citation-based subcommunities exist within the field, and how they can be characterized. Secondly, we will describe their development over time in order to assess whether developments towards an increasingly emancipated field or even a discipline are visible. To assess this, absolute measures of interconnectedness within scholarly communities are difficult to use, as it is difficult to determine what extent of homogeneity is needed for a field to be deemed a discipline - but relative measures, such as comparisons over time, enable observers to identify trends. Thirdly, we will assess the interconnections between the different subcommunities.

\section{Data and methods}

Co-citation analysis was used to explore the development of scholarship on science communication between 1996 and 2015. This method is mainly applied in bibliometrics [Moed, 2005] to measure researcher performance [Nightingale and Marshall, 2012], or to analyze the development of concepts such as Corporate Social Responsibility over time [De Bakker, Groenewegen and Den Hond, 2005]. Such studies typically base their samples on specific (sets of) journals representing a discipline or research field of interest.

Generally, several databases can be used for citation analyses. We chose the Scopus database. On the one hand, it covers a number of non-English journals as well as edited volumes and some books which are not included in the Social Science Citation Index, providing a better foundation for the analyses of a (potentially) international research field that is largely based in the social sciences [Gasparyan, Ayvazyan and Kitas, 2013]. On the other hand, it is less inclusive than Google Scholar which also includes graduate and undergraduate theses as well as conference presentations and, thus, ensures a better coverage of the research field itself.

To acquire an initial set of publications as a starting point for our analysis, we used the keywords 'science communication' or 'scientific communication' in Scopus' internal search tool. The condition for inclusion in the initial sample was that at least one of the search terms had to appear either in the title, abstract or key words of a publication (with non-English articles on Scopus usually having an English abstract, enabling us to search them as well). Before proceeding with our analysis, we checked for potential biases caused by the inclusion of the keyword "scientific communication". Overall, this keyword yielded only few additional publications: only 328 publications were included in the analysis that included "scientific communication" exclusively, and all other publications included "science communication" as well. In addition, the most frequently quoted literature in these publications is the same as in the rest of the sample [e.g. Latour, 1987; Kuhn, 1962; Merton, 1973], which shows that at least in terms of citations there is a connection between the inward-oriented "scientific communication" and the more outward-oriented "science communication".

As Scopus does not fully cover scientific publications before 1996 [Gasparyan, Ayvazyan and Kitas, 2013], we only included publications from 1996 until 2015. 
Based on these criteria, a cleansed corpus consisting of 2395 scholarly publications could be identified, with full bibliographic information and abstracts available. ${ }^{2}$ This wide selection of publications was further reduced at a later stage based on the results of the citation networks.

To prepare the data for co-citation analysis [Small, 1973], we first extracted all references from each publication and created bibliographic couples for each combination of references. These bibliographic couples were then merged and further used as an undirected edge table for a network analysis with the R-package igraph [Csárdi and Nepusz, 2006]. For the final analysis, only publications that were cited in at least three documents were included in the co-citation analysis. ${ }^{3}$

With the edge list, an undirected network consisting of 1815 nodes (unique references) and 53,294 edges (bibliographic couples) was created. In a next step, we further reduced the network and considered only edges with a minimum weight of two. Based on this reduced network with only 7703 edges, different communities could be identified through modularity-based community detection. One of the most efficient and well established methods is the Louvain-Algorithm [Blondel et al., 2008]. Instead of using similarity measures, this approach relies solely on the topology of the network and can incorporate the weights of the edges [Wallace, Gingras and Duhon, 2009]. Each unique reference can be assigned to a specific community. We only used communities with at least 20 unique references for further analysis. Our final analysis included 1238 unique references and 1051 of our original documents. The strong reduction is not surprising, because we were selecting our data only based on two general search terms.

In a next step, the original 1051 documents were classified based on the references they used. If the majority of the quoted references in a document belongs to a specific community, the document was classified as being part of this community.

In the penultimate step, we identified research topics in the abstracts of the documents using automated content analysis [Latent Dirichlet Allocation (LDA): Blei, $\mathrm{Ng}$ and Jordan, 2003]. This method is particularly useful in studying scientific topics as the seminal study of Griffiths and Steyvers [Griffiths and Steyvers, 2004] has demonstrated. Abstracts usually include all the relevant topics of an academic publication. We conducted the LDA with the program MALLET [McCallum, 2002], within R. ${ }^{4}$ Parameters for the LDA were chosen based on Steyvers and Griffiths [2007]. Asymmetric dirichlet priors over the document - topic distributions were

\footnotetext{
${ }^{2}$ For articles and book chapters with up to three authors, the publication year and page numbers were included in the id. With this step, it was possible to distinguish multiple publications by the same author(s) in the same year.

${ }^{3}$ Researchers usually use such thresholds in co-citation analyses. In the past, these thresholds were often very high in order to reduce the amount of data, as computational power was a limiting factor. With these limitations being less salient nowadays, we can conduct citation analyses with considerably larger data sets. Still, however, setting a threshold is useful to receive more refined solutions. Accordingly, we decided to use a threshold as low as possible that still provides a clear solution [see also Klavans and Boyack, 2017; Trujillo and Long, 2018]. The threshold of three used here means that a bibliographic title had to be quoted in at least $1.2 \%$ of our 2.395 publications.

${ }^{4}$ Before running the model stop words were filtered based on the list available in MALLET including the words we used as search terms (scientific, science and communication), all numbers were deleted, hyphens were replaced with space characters and all words were converted to lower-case.
} 
used [Wallach, Mimno and McCallum, 2009]. ${ }^{5}$ After multiple preliminary runs with different numbers of topics (k), a model with ten topics was chosen for analysis. The topics with the highest probability were also present in models with a lower number of topics. More than ten topics did not provide further insights. The following topics were identified (with the respective words being ordered by their probability of appearing in the respective topics):

1. Models \& Theories including the words "information model system paper models theory systems process studies technology concept concepts based complex scholarly";

2. Open Access, including "access open information internet publishing web research scientists data impact world system traditional process scholarly";

3. Higher Education, containing the words "students education learning skills university results understanding study higher high group knowledge nature professional groups";

4. Scientific Networks, including "social network community networks research sciences field knowledge collaboration disciplines based approach production fields patterns";

5. Climate Change, with "climate change global political community important policy cultural differences activities perceptions risk data focus human";

6. Scientists \& the Public, containing "public scientists understanding engagement issues technology policy activities work article research communicate people general communicating";

7. Empirical Analysis, with "research study information analysis results studies data findings researchers paper academic countries online content evidence";

8. News Media and Public Communication, containing "media social knowledge news society role article discourse context study political popular cultural debate content";

9. Applied Science Communication, including "research knowledge development review health paper management process quality risk important practice current practices future"; and

10. Citation \& Publication Analysis, with "journals articles journal published authors citation article publication results publications language number literature international impact"

In the final step, the identified communities were combined with the topics identified via LDA in order to provide a more robust description, and differentiation, of the co-citation communities.

\footnotetext{
${ }^{5} \alpha=50 / T$ and $\beta=0.01$. Hyperparameters were optimized every 20 iterations after 50 burn-in iterations. Overall 1000 iterations were used to ensure that the log-likelihood stabilizes.
} 
Identifying

co-citation

communities
Using co-citation analysis based on 1238 unique references and 1051 of our original documents, we found eleven co-citation communities in the scholarly literature on science communication. Subsequently, we assigned individual publications to these communities, and by employing latent dirichlet allocation (LDA) on these publications' abstracts, we could identify the major topics which are used in the respective communities.

Table 1. Description of co-citation-based communities, their size, typical publications and topics.

\begin{tabular}{|c|c|c|c|}
\hline Community & $\mathbf{N}$ & Typical Publications & Characteristic Topics \\
\hline $\begin{array}{l}\text { Sociology of } \\
\text { Science }\end{array}$ & 188 & $\begin{array}{l}\text { Latour [1987]: Science in Action } \\
\text { Kuhn [1962]: The Structure of Scientific Revolutions } \\
\text { Merton [1973]: The Sociology of Science }\end{array}$ & $\begin{array}{l}\text { Models \& Theories / } \\
\text { Citation \& } \\
\text { Publication Analysis }\end{array}$ \\
\hline $\begin{array}{l}\text { Science debates } \\
\text { and the role of } \\
\text { journalism }\end{array}$ & 208 & $\begin{array}{l}\text { Nisbet \& Scheufele [2009]: What's next for science communication? } \\
\text { Boykoff \& Boykoff [2004]: Balance as Bias } \\
\text { Nisbet et al. [2003]: Framing Science }\end{array}$ & $\begin{array}{l}\text { Climate Change / } \\
\text { News Media \& } \\
\text { Public } \\
\text { Communication }\end{array}$ \\
\hline $\begin{array}{l}\text { Dissemination of } \\
\text { Science via Media }\end{array}$ & 247 & $\begin{array}{l}\text { Gregory \& Miller [1998]: Science in Public } \\
\text { Nelkin [1995]: Selling Science } \\
\text { Hilgartner [1990]: The dominant view of popularization }\end{array}$ & $\begin{array}{l}\text { News Media \& } \\
\text { Public } \\
\text { Communication }\end{array}$ \\
\hline $\begin{array}{l}\text { Scholarly } \\
\text { Communication }\end{array}$ & 80 & $\begin{array}{l}\text { Garvey [1979]: Communication: The Essence of Science } \\
\text { Borgman [2007]: Scholarship in the Digital Age } \\
\text { Tenopir \& King [2000]: Towards Electronic Journals }\end{array}$ & $\begin{array}{l}\text { Open Access / } \\
\text { Citation \& } \\
\text { Publication Analysis }\end{array}$ \\
\hline $\begin{array}{l}\text { Scientists as } \\
\text { Communicators }\end{array}$ & 94 & $\begin{array}{l}\text { Davies [2008]: Constructing communication: Talking to scientists } \\
\text { about talking to the public. } \\
\text { Besley \& Tanner [2011]: What science } \\
\text { communication scholars think about training scientists to } \\
\text { communicate } \\
\text { Bonetta [2007]: Scientists Enter the Blogosphere }\end{array}$ & $\begin{array}{l}\text { Scientists \& the } \\
\text { Public }\end{array}$ \\
\hline $\begin{array}{l}\text { Media effects on } \\
\text { the broader } \\
\text { public }\end{array}$ & 46 & $\begin{array}{l}\text { Nisbet et al. [2008]: Knowledge, reservations, or promise? A media } \\
\text { effects model for public perceptions of science and technology } \\
\text { Miller [1983]: Scientific Literacy } \\
\text { Lee \& Scheufele [2006]: The influence of knowledge and deference } \\
\text { toward scientific authority: A media effects model }\end{array}$ & Emp \\
\hline From PUS to PEST & 209 & $\begin{array}{l}\text { Bauer et al. [2007]: What can we learn from } 25 \text { years of PUS survey } \\
\text { research? Liberating and expanding the agenda. } \\
\text { Irwin \& Wynne [1996]: Misunderstanding science? } \\
\text { Miller [2001]: Public understanding of science at the crossroads }\end{array}$ & $\begin{array}{l}\text { Scientists \& the } \\
\text { Public }\end{array}$ \\
\hline $\begin{array}{l}\text { Science } \\
\text { Education }\end{array}$ & 54 & $\begin{array}{l}\text { Bell et al. [2009]: Learning Science in Informal Environments } \\
\text { Ziman [2000]: Real science: What it is, and what it means } \\
\text { Falk \& Dierking [2000]: Learning from Museums }\end{array}$ & ducation \\
\hline $\begin{array}{l}\text { Open Access and } \\
\text { digital publishing }\end{array}$ & 23 & $\begin{array}{l}\text { Lawrence [2001]: Online or invisible? } \\
\text { Johnson [2002]: Institutional Repositories } \\
\text { Antelman [2004]: Do open access articles have a greater research } \\
\text { impact? }\end{array}$ & Ope \\
\hline $\begin{array}{l}\text { Information } \\
\text { networks in } \\
\text { science }\end{array}$ & 26 & $\begin{array}{l}\text { Shannon \& Weaver [1949]: The Mathematical Theory of } \\
\text { Communication. } \\
\text { Girvan \& Newman [2002]: Community structure in social and } \\
\text { biological networks } \\
\text { Watts \& Strogatz [1998]: Collective dynamics of 'small-world' } \\
\text { networks }\end{array}$ & $\begin{array}{l}\text { Scientific Networks / } \\
\text { Models and } \\
\text { Theories }\end{array}$ \\
\hline $\begin{array}{l}\text { Applied Science } \\
\text { Communication }\end{array}$ & 63 & $\begin{array}{l}\text { Jasanoff [1990]: The Fifth Branch, Science Advisers As Policy Makers. } \\
\text { Fischhoff [1995]: Risk perception and communication unplugged: } \\
\text { twenty years of process } \\
\text { Slovic [1993]: Perceived risk, trust, and democracy }\end{array}$ & $\begin{array}{l}\text { Applied Science } \\
\text { Communication }\end{array}$ \\
\hline
\end{tabular}


The analyzed publications cover a broad topical spectrum. They include the communication of science to outside audiences via new media and science education as well as scholarly communication and bibliometric studies (see Table 1). To identify the communities, we combined the results of the co-citation analysis with the results of the topic models (see Figure 1). Based on the results, the following subcommunities could be identified:

1. 'Sociology of Science' constitutes one of the largest communities with 188 publications. This community typically cites publications analyzing sociological aspects of science: on the macro-level, facets like the influence of social communities for the development of entire scientific paradigms and for the trajectory of science itself [Kuhn, 1962]; on the meso-level, the social norms and mechanisms of scientific communities [Merton, 1973]; and on the micro-level, the role of social influences on scientific work inside the laboratory [Latour, 1987]. Accordingly, this community is strongly associated with the "Models \& Theories" topic, as well as with "Citation and Publication Analysis".

2. 'Science Debates and the Role of Journalism' represents one of the largest communities, too, with 208 publications. This community typically quotes relatively recent publications on the role of media and public debates for science [Boykoff and Boykoff, 2004; cf. Fischhoff and Scheufele, 2013]. It focuses on science debates in the public, recognizing that science communication often, and maybe increasingly, takes place in a social, often political environment [Scheufele, 2013; Scheufele, 2014]. It concentrates on appropriate communication strategies to successfully communicate science in such situations [Nisbet, Brossard and Kroepsch, 2003], and on fruitful ways to improve science communication in the future [Nisbet and Scheufele, 2009]. It can be characterized by the "News Media \& Public Communication" topic and by the "Climate Change" topic which has been a recent emphasis within science communication [Schäfer, 2015].

3. The 'Media Dissemination of Science' community shows similarities to "Science debates and the role of journalism" in that it is also large, containing 247 publications, and focuses on the "News Media \& Public Communication" topic. In contrast to the previous community, however, it represents more classic texts focusing on, or sometimes criticizing, a more traditional understanding of science communication via media in which the media play the role of a disseminator [Gregory and Miller, 1998; Hilgartner, 1990].

4. 'Scholarly Communication', in contrast to the abovementioned communities, is focused on inner-scientific, scholarly communication. The community is medium-sized with 80 publications. It deals with the general role of communication as an essential characteristic of science [Garvey, 2014], as well as with formal scientific communication via publications and its current changes towards digital publishing [Borgman, 2010; Tenopir and King, 2000].

5. 'Scientists as Communicators', another medium-sized community with 94 titles, concentrates on individual scientists as communicators. The publications assembled here analyse, for example, the perceptions, aims and strategies of scholars when they communicate with the public [Besley and Tanner, 2011; Davies, 2008] and when they engage on online communication 
[Bonetta, 2007; Bonetta, 2009]. Accordingly, the topic "Scientists \& the Public" characterizes this community best.

6. 'Media Effects on the Broader Public' is a small community which contains 46 publications. Its specific focus lies on the effects of media communication about science on "lay" audiences, which it analyses on an individual level using standardized methodology taken from psychology and communication science. Early on, this community focused on cognitive effects, particularly on the scientific literacy of the audience [Miller, 1983], whereas later, the understanding of such a literacy broadened [Miller, 1998] and other, non-cognitive perceptions of science were also included [Nisbet et al., 2002]. In line with the empirical focus of this community, it is characterized by the "Empirical Analysis" topic.

7. 'From PUS to PEST' is a large community, consisting of 209 publications, which is mainly concerned with the development of interactions between scientists and the public. The publications assembled here often deal with the underlying models of science communication and their development from "Public Understanding of Science" (PUS) to more dialogical, participatory modes of "Public Engagement with Science and Technology" (PEST) [Bauer and Bucchi, 2007; Irwin and Wynne, 1996; Miller, 2001]. In comparison to the "Media Dissemination of Science" community, the role of the media is less focused upon here in favor of the broader interactions between science and society.

8. 'Science Education' is a small community which contains 54 publications. Research in this community mainly focuses on the educational aspects of teaching science or distributing scientific knowledge in formal learning contexts like schools or universities, or in informal ones like museums [Falk and Dierking, 2000; cf. Bell, 2009]. Scientific literacy as a concept is discussed critically in this community [Shamos, 1995]. In line with the general focus of the community, the topic "Education" dominates.

9. 'Open Access' is a community which, like the "Scholarly Communication" community, focuses on inner-scientific communication. With only 23 publications, however, it is smaller and focuses on a specific aspect of scholarly communication: open access [Lawrence, 2001]. It weighs advantages and disadvantages of 'green', 'gold' and other forms of open access, such as increased visibility and a positive impact on research [Antelman, 2004], and discusses ways to organize open access publications, e.g. in repositories [Johnson, 2002].

10. 'Information Networks in Science' is another small community with 26 publications. Research in this community heavily relies on the mathematical model of communication [Shannon and Weaver, 1949] and implements the method of network analysis to identify communication structures in various scientific disciplines and research fields [Leydesdorff and Rafols, 2009], or social structures in school classes [Conlan et al., 2011]. In line with the methodological focus of the community "Scientific Networks" and "Models and Theories" are the strongest topics.

11. 'Applied Science Communication' is a medium-sized community with 63 publications, which is mainly concerned with applied science communication in fields such as health and risk communication. Research in this community 
focuses on science policy [Jasanoff, 1990], risk communication as well as on citizens' risk perceptions [Slovic, 1993]. Many studies belonging to this community are practical in nature and have a direct impact on science communicators such as environment or health professionals [Grossberndt, van den Hazel and Bartonova, 2012]. As the typically cited literature in this community indicates, "Applied Science Communication" is one of the most important topics in this community.

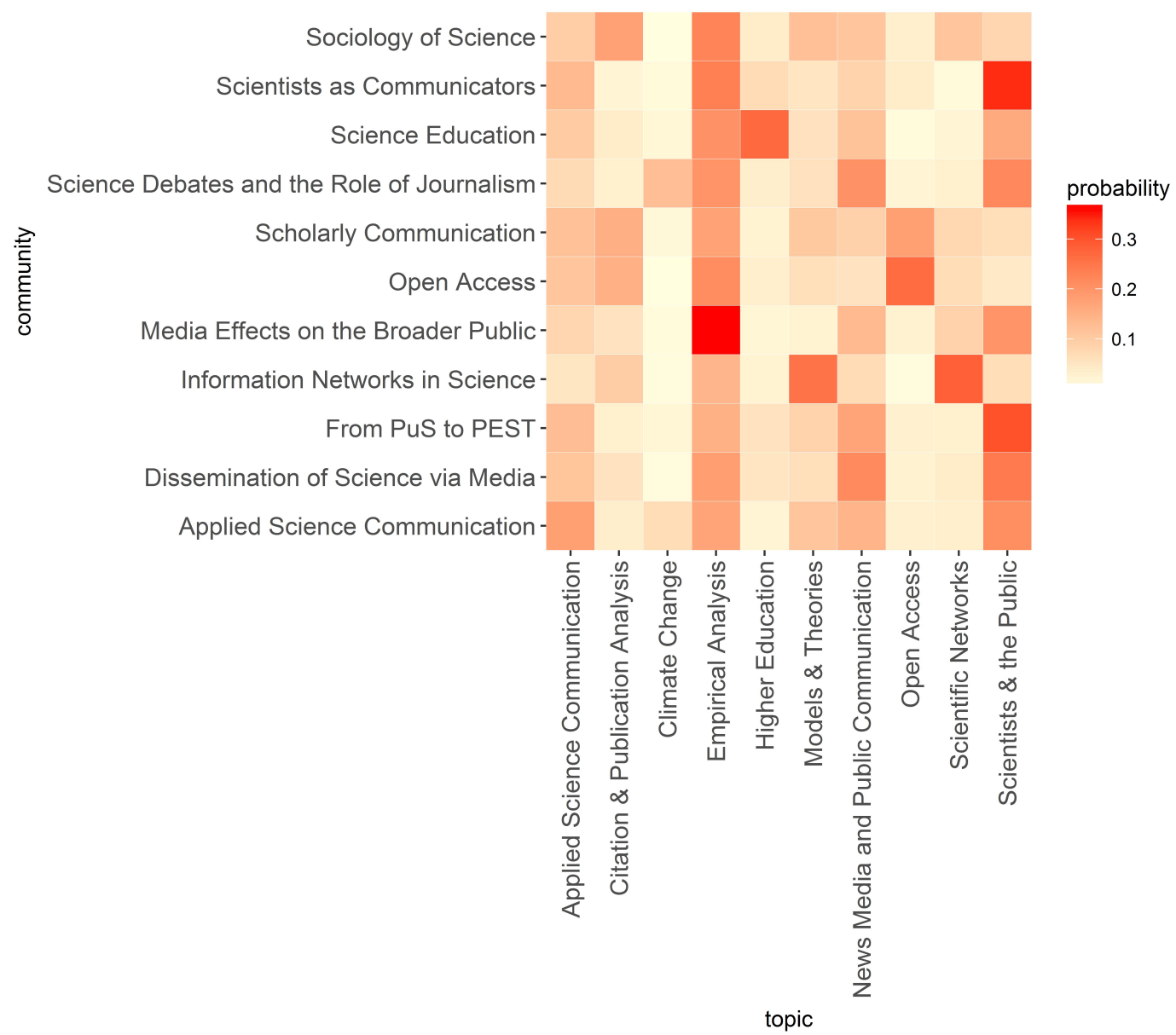

Figure 1. Relevance of different topics in the co-citation-based communities. (figure shows normalized probabilities, i.e. sum to 1 over all topics).

How have the subcommunities developed over time?
Over time, science communication research has grown considerably. Within this growing field, however, the eleven communities identified in the first step developed differently. This is clearly visible in our data, which shows that the cited literature has shifted away from the previously dominant 'Sociology of Science' community (see Figure 2). Early on, literature from the 'Sociology of Science' clearly was the most quoted in the field. But, as Figure 2 reveals, that there has been a gradual increase in citations from other communities, most notably from those focusing specifically on media communication and outside communication of the scientific community. Overall the breadth of scholarship increased [cf. Schäfer, 2012], with communities like 'Scientists as Communicators', 'Media Effects on the Broader Public', 'From PUS to PEST' or 'Science Debates and the Role of 
Journalism' emerging and gaining in importance. As of now, there is a relative dominance of communities that have (mediated) communication at their core: 'Media Dissemination of Science', 'From PUS to PEST', and 'Science Debates and the Role of Journalism'.
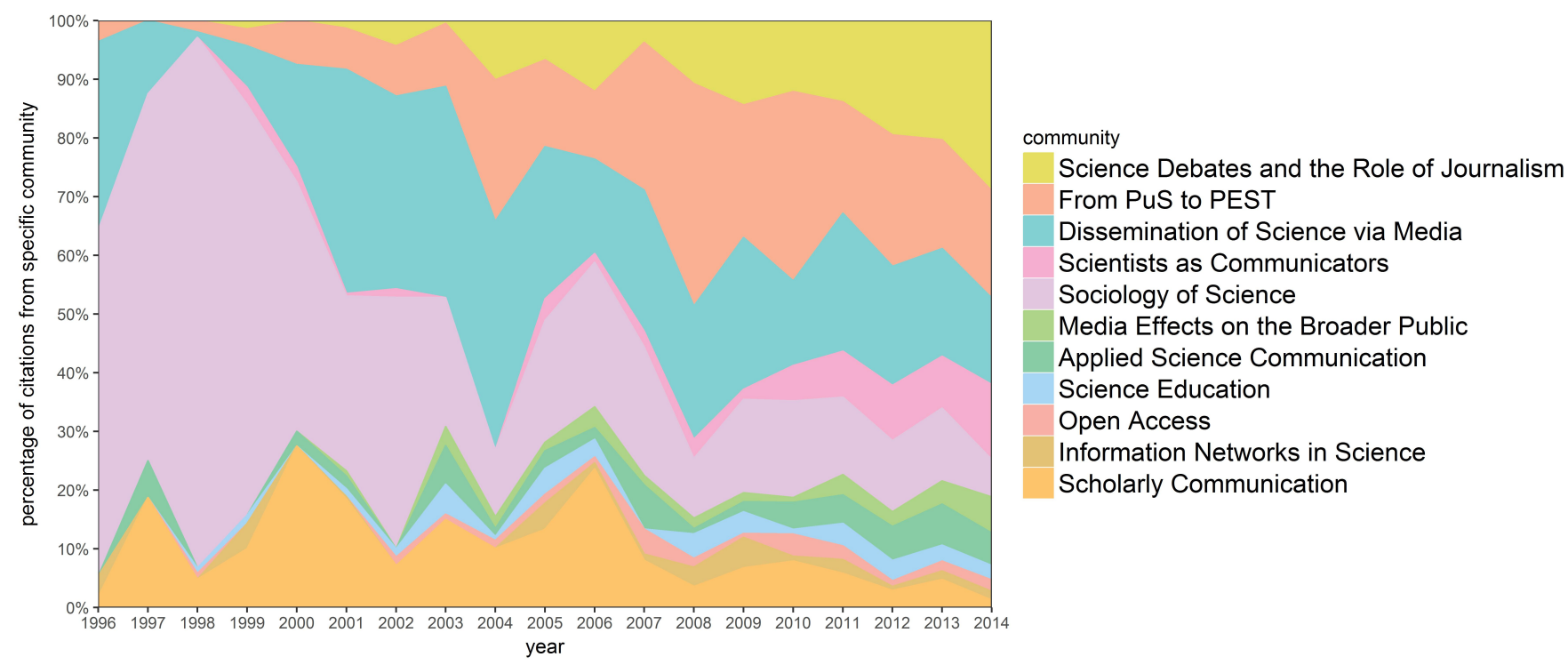

Figure 2. Relative importance of different communities over time (figure shows percentage of all citations by community).

Even though the 'Sociology of Science' literature is quoted less often in relation to other communities in recent years, the absolute number of citations from this community has risen over time, along with the growth of the entire field. The 'Sociology of Science' has exhibited a steady growth over the last twenty years together with the other three largest communities (see Figure 3). Still, however, the gap between the 'Sociology of Science' and 'Science Debates and the Role of Journalism' became larger in recent years. In 2014, the 'Science Debates and the Role of Journalism' literature was quoted three times as often as the 'Sociology of Science' literature.

In our third analytical step, we assess the proximity and interconnections between the communities. After we classified the cited literature, we checked how often literature from each community was cited together, i.e. in the same scientific publication, with literature from the same or other communities. This allows us to measure the relative distance between the communities, and to visualize the results using multidimensional scaling (MDS) [Cox and Cox, 2000]. We used the vegan package in $\mathrm{R}$ to calculate a dissimilarity matrix with the Jaccard index [Oksanen et al., 2016]. ${ }^{6}$

The MDS visualization shows a close proximity between the three communities which are, currently, quoted most often (see Figure 4). 'Science Debates and the Role of Journalism', 'From PUS to PEST', and 'Media Dissemination of Science' are all concerned with aspects of mediated science communication, and are often

\footnotetext{
${ }^{6}$ Additionally, we conducted a hierarchical cluster analysis to assess which communities can be grouped together. This analysis confirmed the visual interpretation of the MDS: the communication-centric communities can be grouped together.
} 


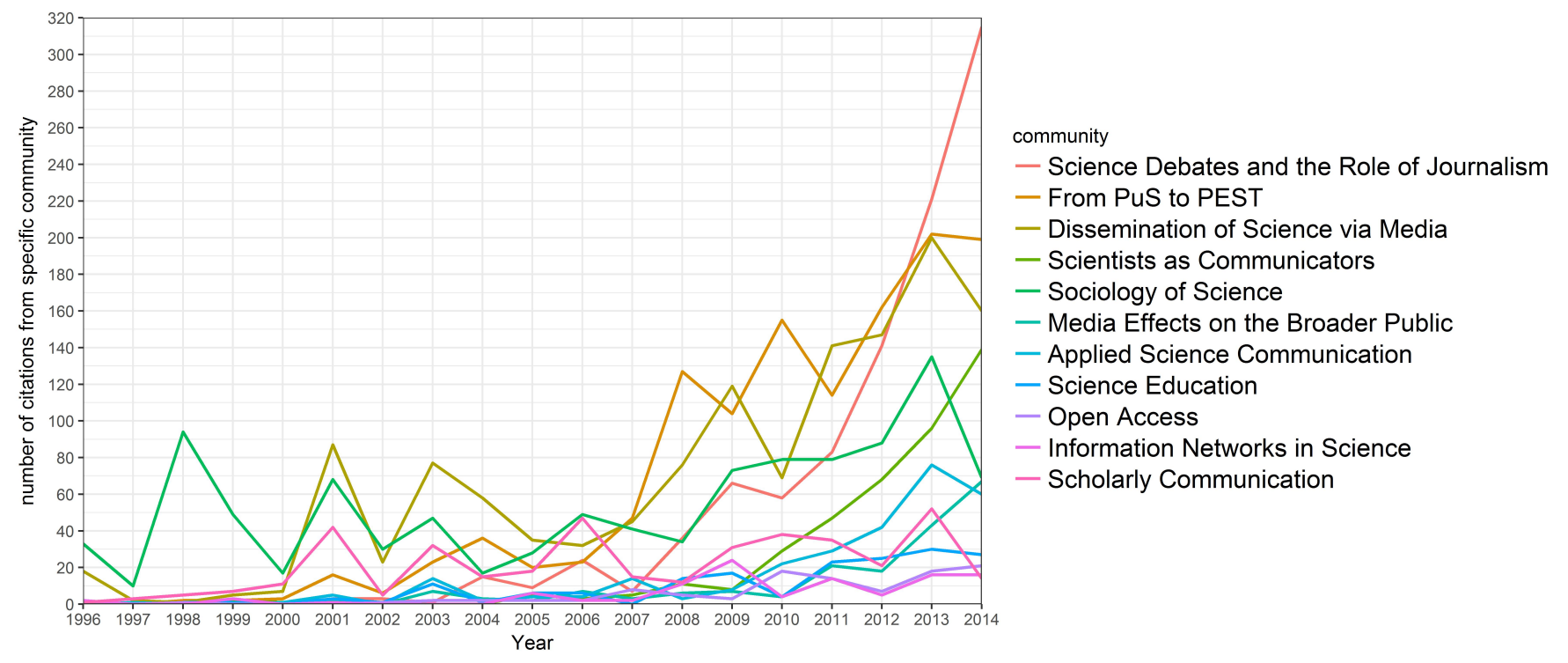

Figure 3. Relative importance of different communities over time (figure shows percentage from the different communities).

quoted together in studies of science communication. 'Applied Science Communication', 'Science Education', 'Scientists as Communicators', and 'Media Effects on the Broader Public' are another group of communities that are proximate and, accordingly, often cited together. The other four communities are more distanced from these two groups. Interestingly, the 'Sociology of Science' community does not belong to one of the groups, but has a central position in the research on science communication. This indicates that this literature is not sistematically quoted together with literature from specific other communities, but still of importance for all other communities.

Discussion

Using co-citation analysis allowed us to identify eleven distinct subcommunities within science communication research. These communities are of varying size, characterized by different research foci and epistemological traditions, and have developed differently in the last 20 years.

The results for all three research questions - i.e. regarding the existing communities, their development and their proximity to each other - indicate a number of distinct developments. The field has shifted away from the 'Sociology of Science', a subcommunity that is deeply rooted in sociology and has focused strongly on the scientific system and its actors, towards communities which are more media- and communication-centric. Overall, however, the literature of the 'Sociology of Science' community is still quoted often. This can be explained with the most quoted literature from this community. Classics such as Latour [1987], Kuhn [1962] and Merton [1973], which are basic references for many science communication scholars, and accordingly, quoted from various communities. Empirically, this can be observed in the MDA as an isolated yet central position of the 'Sociology of Science' community literature in the SSC. It is also evident when the absolute numbers of citations are analyzed, which were still rising over time for 


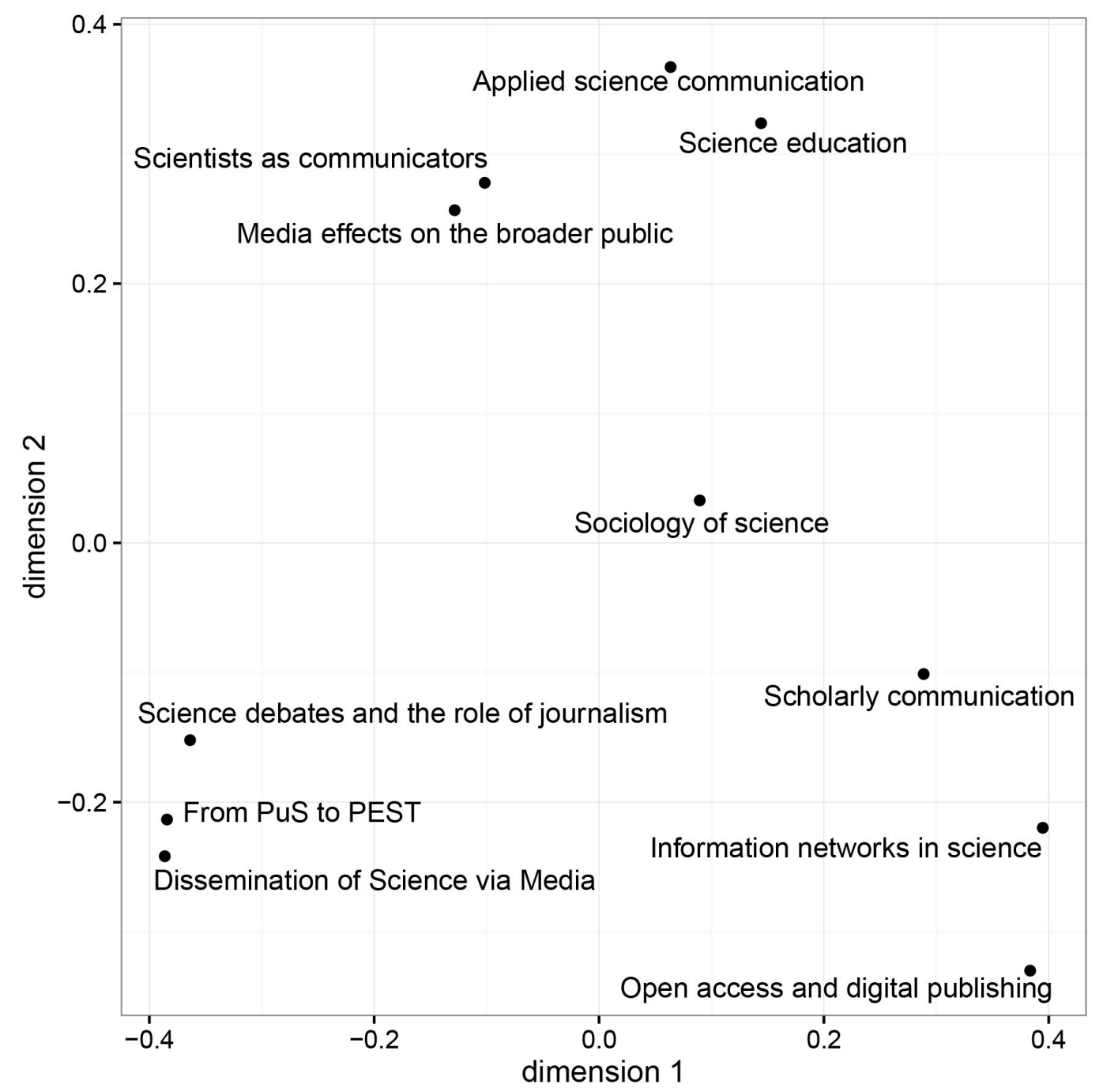

Figure 4. Proximity of the different communities (figure shows result of multidimensional scaling analysis).

the 'sociology of science' - even though the rise of communication- and media-centric was even more pronounced. ${ }^{7}$

Regarding the development of science communication research, our analysis of citation networks shows that the research field has differentiated itself over the years. Not only did the communication- and media-centric communities emerge and rise in importance, educational and practitioner-oriented literature became more important as well. Still, however, our findings suggest that the communication-centric communities have become the core of the field, accounting for over $50 \%$ of all citations in 2014 . This figure could rise even further, as the literature from these communities is more recent than that from other communities. It has mostly been published in the last decade, and the future has to show if it will reach a half-life period similar to the 'Sociology of Science' literature that has been mostly published before the 1990s.

\footnotetext{
${ }^{7}$ Still, this data must be interpreted with caution because the literature of the 'Science debates and the role of journalism' community is still very new and citations have most likely not yet reached their half-life [Abt, 1998].
} 
It will be interesting to see whether these communities will move even closer together in the future - which would be a clear sign of a maturing, and increasingly emancipated, field. Our analysis has shown that the communities have already come closer, and cover a wide range of methods and topics. Science communication research has become a well-developed research field, at least with regards to the indicator we have used here: scholarly citation networks. The future development of the other two axes of disciplinary development, i.e. of institutional and epistemological characteristics, will have to show if the field can further its institutionalization and, maybe, move towards a distinct discipline. Currently, it is too early for a final assessment.

These results come with some caveats, however, as this study has a number of limitations. The first and most obvious one is that we have only focused on the scholarly communication to assess the development of the field. Therefore, we caution for early conclusions, and advice to further investigate the other 'axes' mentioned above.

Another possible weakness is the use of only two keywords at the outset of the study, and of one of them being "scientific communication". Even though we checked the keyword seeds for potential biases, this strategy can be debated and analyses using other, alternative strategies would be helpful. They could use more specific keywords such as "science journalism", for example, to select the initial article sample, as there may be a considerable amount of publications not explicitly mentioning "science communication" or "scientific communication" as a keyword. A different strategy, which is typically implemented in bibliometric studies, would be to use a sample based on articles from specific journals. While this might have been appropriate for the analysis of a different, more mature field or discipline. At the current state of research on science communication, however, it seemed inappropriate as the respective literature is being published in a wide range of disciplinary journals. Nonetheless, a variety of approaches would certainly be helpful to describe the characteristics and developments of a research field as diverse and dynamic as studies on science communication.

\section{References}

Abt, H. A. (1998). 'Why some papers have long citation lifetimes'. Nature 395 (6704), pp. 756-757. https://doi.org/10.1038/27355.

Antelman, K. (2004). 'Do open-access articles have a greater research impact?' College \& Research Libraries 65 (5), pp. 372-382. https://doi.org/10.5860/crl.65.5.372.

Bauer, M. W. (2009). 'The Evolution of Public Understanding of Science Discourse and Comparative Evidence'. Science, Technology and Society 14 (2), p. 221. https://doi.org/10.1177/097172180901400202.

- (2016). 'Results of the essay competition on the 'deficit concept'. Public Understanding of Science 25 (4), pp. 398-399. https://doi.org/10.1177/0963662516640650.

Bauer, M. W., Allum, N. and Miller, S. (2007). 'What can we learn from 25 years of PUS survey research? Liberating and expanding the agenda'. Public Understanding of Science 16 (1), pp. 79-95. https://doi.org/10.1177/0963662506071287. 
Bauer, M. W. and Bucchi, M., eds. (2007). Journalism, Science and Society: between News and Public Relations. London, U.K.: Routledge. https://doi.org/10.4324/9780203942314.

Bell, L. (2009). 'Engaging the public in public policy'. Museums $\mathcal{E}$ Social Issues 4 (1), pp. 21-36. https://doi.org/10.1179/msi.2009.4.1.21.

Besley, J. C. and Tanner, A. H. (2011). 'What Science Communication Scholars Think About Training Scientists to Communicate'. Science Communication 33 (2), pp. 239-263. https://doi.org/10.1177/1075547010386972.

Blei, D. M., Ng, A. Y. and Jordan, M. I. (2003). 'Latent Dirichlet Allocation'. Journal of Machine Learning Research 3, pp. 993-1022. URL: http://www.jmlr.org/papers/volume3/blei03a/blei03a.pdf.

Blondel, V. D., Guillaume, J.-L., Lambiotte, R. and Lefebvre, E. (2008). 'Fast unfolding of communities in large networks'. Journal of Statistical Mechanics: Theory and Experiment 2008 (10), P10008. https://doi.org/10.1088/1742-5468/2008/10/p10008.

Bonetta, L. (2007). 'Scientists Enter the Blogosphere'. Cell 129 (3), pp. 443-445. https://doi.org/10.1016/j.cell.2007.04.032.

— (2009). 'Should you be tweeting?' Cell 139 (3), pp. 452-453. https://doi.org/10.1016/j.cell.2009.10.017.

Bonfadelli, H., Fähnrich, B., Lüthje, C., Milde, J., Rhomberg, M. and Schäfer, M. S. (2018). Forschungsfeld Hochschulkommunikation. Wiesbaden, Germany: Springer VS.

Borgman, C. L. (2010). Scholarship in the digital age: information, infrastructure and the Internet. Cambridge, MA, U.S.A.: MIT Press.

Boykoff, M. T. and Boykoff, J. M. (2004). 'Balance as bias: global warming and the US prestige press'. Global Environmental Change 14 (2), pp. 125-136. https://doi.org/10.1016/j.gloenvcha.2003.10.001.

Bucchi, M. (1998). Science and the Media. New York, U.S.A.: Routledge.

- (2008). 'Of deficits, deviations and dialogues: theories of public communication of science'. In: Handbook of Public Communication of Science and Technology. Ed. by M. Bucchi and B. Trench. London, U.K. and New York, U.S.A.: Routledge, pp. 57-76.

Bucchi, M. and Trench, B., eds. (2014). Routledge Handbook of Public Communication of Science and Technology. 2nd ed. London, U.K. and New York, U.S.A.: Routledge. https://doi .org/10.4324/9780203483794.

Bulick, S. (1982). Structure and subject interaction: toward a sociology of knowledge in the social sciences. in "Books in library and information science", volume 41. New York, U.S.A.: Marcel Dekker Inc.

Callon, M. (1995). 'Four models for the dynamics in science'. In: Handbook of Science and Technology Studies. Ed. by S. Jasanoff, G. E. Markle, J. C. Peterson and T. Pinch. 2nd ed. Thousand Oaks, CA, U.S.A., London, U.K. and New Delhi, India: Sage, pp. 29-63. ISBN: 9780262035682. https://doi.org/10.4135/9781412990127.n2.

Conlan, A. J. K., Eames, K. T. D., Gage, J. A., von Kirchbach, J. C., Ross, J. V., Saenz, R. A. and Gog, J. R. (2011). 'Measuring social networks in British primary schools through scientific engagement'. Proceedings of the Royal Society B: Biological Sciences 278 (1711), pp. 1467-1475. https://doi.org/10.1098/rspb.2010.1807.

Cox, T. F. and Cox, M. A. A. (2000). Multidimensional scaling. Boca Raton, U.S.A.: CRC press. 
Csárdi, G. and Nepusz, T. (2006). 'The igraph software package for complex network research'. InterJournal Complex Systems 1695 (5), pp. 1-9.

URL: http://www . interjournal .org/manuscript_abstract.php?361100992.

Davies, S. R. (2008). 'Constructing communication: Talking to scientists about talking to the public'. Science Communication 29 (4), pp. 413-434.

De Bakker, F. G. A., Groenewegen, P. and Den Hond, F. (2005). 'A bibliometric analysis of 30 years of research and theory on corporate social responsibility and corporate social performance'. Business $\mathcal{E}$ Society 44 (3), pp. 283-317. https://doi.org/10.1177/0007650305278086.

Delfanti, A. (2008). 'How-to establish PCST. Two handbooks on science communication'. JCOM 7 (4), R01. URL: http://jcom. sissa.it/archive/07/04/Jcom0704\%282008\%29R01.

Diodato, V. P. and Gellatly, P. (2013). Dictionary of bibliometrics. Abingdon, U.K.: Routledge.

Dunwoody, S. (1980). 'The science writing inner club: a communication link between science and the lay public'. Science, Technology and Human Values 5 (30), pp. 14-22. URL: https://www . jstor.org/stable/689304.

Fähnrich, B., Metag, J., Post, S. and Schäfer, M. S., eds. (2018). Forschungsfeld Hochschulkommunikation. Wiesbaden, Germany: Springer VS. https://doi.org/10.1007/978-3-658-22409-7.

Falk, J. H. and Dierking, L. D. (2000). Learning from Museums: Visitor Experiences and the Making of Meaning. Walnut Creek, CA, U.S.A.: AltaMira Press.

Fischhoff, B. and Scheufele, D. A. (2013). 'The science of science communication'. Proceedings of the National Academy of Sciences 110 (Supplement 3), pp. 14031-14032. https://doi .org/10.1073/pnas.1312080110. PMID: 23942127.

Freire, P. (1985). The politics of education: culture, power, and liberation. U.S.A.: Greenwood Publishing Group.

Garvey, W. D. (2014). Communication: the essence of science. Facilitating information exchange among librarians, scientists, engineers and students. Amsterdam, Netherlands: Elsevier.

Gascoigne, T., Cheng, D., Claessens, M., Metcalfe, J., Schiele, B. and Shi, S. (2010). ‘Is science communication its own field?' JCOM 9 (3), C04.

Gasparyan, A. Y., Ayvazyan, L. and Kitas, G. D. (2013). 'Multidisciplinary bibliographic databases'. Journal of Korean Medical Science 28 (9), p. 1270. https://doi.org/10.3346/jkms.2013.28.9.1270.

Good, G. A. (2000). 'The assembly of geophysics: scientific disciplines as frameworks of consensus'. Studies in History and Philosophy of Science Part B: Studies in History and Philosophy of Modern Physics 31 (3), pp. 259-292. https://doi.org/10.1016/s1355-2198(00)00018-6.

Goodell, R. (1977). The visible scientists. Boston, U.S.A.: Little, Brown and Co.

Gregory, J. and Miller, S. (1998). Science in public: communication, culture, and credibility. London, U.K. and New York, U.S.A.: Plenum.

Griffiths, T. L. and Steyvers, M. (2004). 'Finding scientific topics'. Proceedings of the National Academy of Sciences 101 (Supplement 1), pp. 5228-5235. https://doi .org/10.1073/pnas. 0307752101.

Grossberndt, S., van den Hazel, P. and Bartonova, A. (2012). 'Application of social media in the environment and health professional community'. Environmental Health 11 (Supplement 1), S16.

https://doi.org/10.1186/1476-069x-11-s1-s16. 
Guenther, L. and Joubert, M. (2017). 'Science communication as a field of research: identifying trends, challenges and gaps by analysing research papers'. JCOM 16 (02), A02. URL: https://jcom.sissa.it/archive/16/02/JC0M_1602_2017_A02.

Gurabardhi, Z., Gutteling, J. M. and Kuttschreuter, M. (2004). 'The development of risk communication'. Science Communication 25 (4), pp. 323-349.

https://doi.org/10.1177/1075547004265148.

Hall Jamieson, K., Kahan, D. M. and Scheufele, D. A., eds. (2017). The Oxford handbook of the science of science communication. Oxford, U.K.: Oxford University Press. https://doi.org/10.1093/oxfordhb/9780190497620.001.0001.

Hilgartner, S. (1990). 'The Dominant View of Popularization: Conceptual Problems, Political Uses'. Social Studies of Science 20 (3), pp. 519-539. https://doi.org/10.1177/030631290020003006.

Irwin, A. and Wynne, B. (1996). Misunderstanding Science? The Public Reconstruction of Science and Technology. Cambridge, U.K.: Cambridge University Press. https://doi.org/10.1017/cbo9780511563737.

Jasanoff, S. (1990). The Fifth Branch. Science Advisers as Policymakers. Cambridge, MA, U.S.A.: Harvard University Press.

Jasanoff, S., Markle, G. E., Peterson, J. C. and Pinch, T., eds. (1995). Handbook of Science and Technology Studies. 2nd ed. Thousand Oaks, CA, U.S.A., London, U.K. and New Delhi, India: Sage. ISBN: 9780262035682. https://doi.org/10.4135/9781412990127.

Johnson, R. K. (2002). 'Institutional repositories: partnering with faculty to enhance scholarly communication'. D-Lib Magazine 8 (11). URL: http://www. dlib.org/dlib/november02/johnson/11johnson.html.

Kahan, D. M. (2016). “Ordinary science intelligence': a science-comprehension measure for study of risk and science communication, with notes on evolution and climate change'. Journal of Risk Research 20 (8), pp. 995-1016. https://doi.org/10.1080/13669877.2016.1148067.

Klavans, R. and Boyack, K. W. (2017). 'Research portfolio analysis and topic prominence'. Journal of Informetrics 11 (4), pp. 1158-1174. https://doi.org/10.1016/j.joi.2017.10.002.

Krishnan, A. (2009). What are academic disciplines? Some observations on the disciplinarity vs. interdisciplinarity debate. Southampton, U.K.: National Centre for Research Methods, University of Southampton. URL: http://eprint s.ncrm.ac.uk/783/1/what_are_academic_disciplines.pdf.

Kuhn, T. S. (1962). The structure of scientific revolutions. Chicago, U.S.A.: University of Chicago Press.

Latour, B. (1987). Science in action: How to follow scientists and engineers through society. Cambridge, MA, U.S.A.: Harvard University Press.

Lattuca, L. R. (2002). 'Learning interdisciplinarity: sociocultural perspectives on academic work'. The Journal of Higher Education 73 (6), pp. 711-739. https://doi.org/10.1353/jhe.2002.0054.

Lawrence, S. (2001). 'Free online availability substantially increases a paper's impact'. Nature 411 (6837), p. 521. https : //doi .org/10.1038/35079151.

Lewenstein, B. V. (1995). 'Science and the media'. In: Handbook of Science and Technology Studies. Ed. by S. Jasanoff, G. E. Markle, J. C. Peterson and T. Pinch. 2nd ed. Thousand Oaks, CA, U.S.A., London, U.K. and New Delhi, India: Sage, pp. 343-360. ISBN: 9780262035682.

https : //doi.org/10.4135/9781412990127.n16. 
Leydesdorff, L. and Rafols, I. (2009). 'A global map of science based on the ISI subject categories'. Journal of the American Society for Information Science and Technology 60 (2), pp. 348-362. https://doi .org/10.1002/asi. 20967.

McCallum, A. K. (2002). MALLET: a MAchine Learning for LanguagE Toolkit. URL: http://mallet.cs.umass.edu/.

Merton, R. K. (1973). The sociology of science. Chicago, U.S.A.: University of Chicago Press.

Miller, J. D. (1983). 'Scientific literacy: xa conceptual and empirical review'. Daedalus 112 (2), pp. 29-48. URL: http://www . jstor. org/stable/20024852.

- (1991). The public understanding of science and technology in the U.S.: report to the U.S. National Science Foundation. DeKalb, IL, U.S.A.: National Opinion Research Centre, University of Chicago.

- (1998). 'The measurement of civic scientific literacy'. Public Understanding of Science 7 (3), pp. 203-223. https: //doi.org/10.1088/0963-6625/7/3/001.

Miller, S. (2001). 'Public understanding of science at the crossroads'. Public Understanding of Science 10 (1), pp. 115-120. https://doi.org/10.1088/0963-6625/10/1/308.

Moed, H. F. (2005). Citation analysis in research evaluation. Part of the "Information science and knowledge management" book series, volume 9. Dordrecht, Netherlands: Springer. https://doi .org/10.1007/1-4020-3714-7.

Nightingale, J. M. and Marshall, G. (2012). 'Citation analysis as a measure of article quality, journal influence and individual researcher performance'. Radiography 18 (2), pp. 60-67. https://doi.org/10.1016/j.radi.2011.10.044.

Nisbet, M., Ho, S., Markowitz, E., O'Neill, S., Schäfer, M. S. and Thaker, J., eds. (2017). The Oxford Encyclopedia of Climate Change Communication. 3 Volumes. New York, NY, U.S.A.: Oxford University Press. https://doi.org/10.1093/acref/9780190498986.001.0001.

Nisbet, M. C., Brossard, D. and Kroepsch, A. (2003). 'Framing science: the stem cell controversy in an age of press/politics'. The International Journal of Press/Politics 8 (2), pp. 36-70. https://doi.org/10.1177/1081180X02251047.

Nisbet, M. C. and Scheufele, D. A. (2009). 'What's next for science communication? Promising directions and lingering distractions'. American Journal of Botany 96 (10), pp. 1767-1778. https://doi.org/10.3732/ajb.0900041.

Nisbet, M. C., Scheufele, D. A., Shanahan, J., Moy, P., Brossard, D. and Lewenstein, B. V. (2002). 'Knowledge, Reservations, or Promise? A Media Effect Model for Public Perceptions of Science and Technology'. Communication Research 29, pp. 584-608. https : //doi .org/10.1177/009365002236196.

Oksanen, J., Blanchet, F. G., Kindt, R., Legendre, P., Minchin, P. R., O'Hara, R. B., Simpson, G. L., Solymos, P., Stevens, M. H. H. and Wagner, H. (2016). Package 'vegan'. Version 2.3-5.

Pardo, R. and Calvo, F. (2002). 'Attitudes toward science among the European public: a methodological analysis'. Public Understanding of Science 11 (2), pp. 155-195. https://doi .org/10.1088/0963-6625/11/2/305.

Peters, H. P. (1994). 'Wissenschaftliche Experten in der öffentlichen Kommunikation über Technik, Umwelt und Risiken'. [Scientific experts in public communication of technology, environment and risks]. Kölner Zeitschrift für Soziologie und Sozialpsychologie 46 (Special issue), pp. 163-190.

Ruhrmann, G. (1992). 'Genetic engineering in the press. A review of research and results of content analysis'. In: ed. by J. Durant. London, U.K.: Science Museum, pp. 169-201. 
Schäfer, M. S. (2009). ‘From Public Understanding to Public Engagement: An Empirical Assessment of Changes in Science Coverage'. Science Communication 30 (4), pp. 475-505. https : //doi .org/10.1177/1075547008326943.

- (2011). 'Sources, Characteristics and Effects of Mass Media Communication on Science: A Review of the Literature, Current Trends and Areas for Future Research'. Sociology Compass 5 (6), pp. 399-412. https://doi.org/10.1111/j.1751-9020.2011.00373.x.

- (2012). 'Taking stock: A meta-analysis of studies on the media's coverage of science'. Public Understanding Science 21 (6), pp. 650-663. https://doi.org/10.1177/0963662510387559.

- (2015). 'Climate Change and the Media'. In: International Encyclopedia of the Social \& Behavioral Sciences, 2nd edition, vol. 3, pp. 853-859. https://doi.org/10.1016/b978-0-08-097086-8.91079-1.

Schäfer, M. S. and Schlichting, I. (2014). 'Media Representations of Climate Change: A Meta-Analysis of the Research Field'. Environmental Communication 8 (2), pp. 142-160. https://doi.org/10.1080/17524032.2014.914050.

Scheufele, D. A. (2013). 'Communicating science in social settings'. Proceedings of the National Academy of Sciences 110 (Supplement 3), pp. 14040-14047. https://doi.org/10.1073/pnas.1213275110.

- (2014). 'Science communication as political communication'. Proceedings of the National Academy of Sciences 111 (Supplement 4), pp. 13585-13592. https://doi.org/10.1073/pnas.1317516111.

Schützenmeister, F. (2008). Zwischen Problemorientierung und Disziplin. Ein koevolutionäres Modell der Wissenschaftsentwicklung. [Between problem focus and discipline. A co-evoloutionary model of the development of science]. Bielefeld, Germany: Transcript.

Shamos, M. H. (1995). The myth of scientific literacy. U.S.A.: Rutgers University Press.

Shannon, C. E. and Weaver, W. (1949). The mathematical theory of communication. Urbana, IL, U.S.A.: University of Illinois Press.

Slovic, P. (1993). 'Perceived risk, trust and democracy'. Risk Analysis 13 (6), pp. 675-682. https://doi.org/10.1111/j.1539-6924.1993.tb01329.x.

Small, H. (1973). 'Co-citation in the scientific literature: a new measure of the relationship between two documents'. Journal of the American Society for Information Science 24 (4), pp. 265-269. https://doi.org/10.1002/asi.4630240406.

Steyvers, M. and Griffiths, T. L. (2007). 'Probabilistic topic models'. In: Handbook of Latent Semantic Analysis. Ed. by T. K. Landauer, D. S. McNamara, S. Dennis and W. Kintsch. Mahwah, NJ, U.S.A.: Lawrence Erlbaum Associates, pp. 424-440.

Sugimoto, C. R. and Weingart, S. (2015). 'The kaleidoscope of disciplinarity'. Journal of Documentation 71 (4), pp. 775-794. https://doi.org/10.1108/jd-06-2014-0082.

Tenopir, C. and King, D. W. (2000). Towards electronic journals: realities for scientists, librarians and publishers. Washington, DC, U.S.A.: Special Libraries Association.

Trench, B. and Bucchi, M. (2010). 'Science communication, an emerging discipline'. JCOM 09 (03), C03. URL: http: // jcom. sissa.it/archive/09/03/Jcom0903\%282 010\%29C01/Jcom0903\%282010\%29C03.

Trujillo, C. M. and Long, T. M. (2018). 'Document co-citation analysis to enhance transdisciplinary research'. Science Advances 4 (1), e1701130. https://doi.org/10.1126/sciadv.1701130. 
Wallace, M. L., Gingras, Y. and Duhon, R. (2009). 'A new approach for detecting scientific specialties from raw cocitation networks'. Journal of the American Society for Information Science and Technology 60 (2), pp. 240-246. https://doi.org/10.1002/asi.20987.

Wallach, H. M., Mimno, D. and McCallum, A. (2009). 'Rethinking LDA: why priors matter'. In: Advances in Neural Information Processing Systems 22. Ed. by Y. Bengio, D. Schuurmans, J. D. Lafferty, C. K. I. Williams and A. Culotta, pp. 1973-1981.

Weingart, P. (1998). 'Science and the media'. Research Policy 27 (8), pp. 869-879.

White, H. D. and McCain, K. W. (1998). 'Visualizing a discipline: an author co-citation analysis of information science, 1972-1995'. Journal of the American society for information science 49 (4), pp. 327-355. https: //doi .org/10.1002/ (SI CI) 1097-4571(19980401) 49:4<327: : AID-ASI4>3.0 . CO;2-4.

Authors

Adrian Rauchfleisch, Ph. D., is Assistant Professor at the Graduate Intitute of Journalism at the National Taiwan E-mail: adrian.rauchfleisch@gmail.com.

Mike S. Schäfer, Dr., is Professor of Science Communication at the University of Zurich. E-mail: m.schaefer@ikmz.uzh.ch.

\section{How to cite}

Rauchfleisch, A. and Schäfer, M. S. (2018). 'Structure and development of science communication research: co-citation analysis of a developing field'. JCOM 17 (03), A07. https:/ /doi.org/10.22323/2.17030207. 